\title{
Viewpoint: \\ When Will AI Exceed Human Performance? Evidence from AI Experts
}

Katja Grace

John Salvatier

AI Impacts, Berkeley, USA
KATJA.S.GRACE@GMAIL.COM

J.SALVATIER@GMAIL.COM

ALLAN.DAFOE@GOVERNANCE.AI

BAOBAO.ZHANG@YALE.EDU

OWAINE@GMAIL.COM

Owain Evans

Future of Humanity Institute, University of Oxford, UK

\begin{abstract}
Advances in artificial intelligence (AI) will transform modern life by reshaping transportation, health, science, finance, and the military. To adapt public policy, we need to better anticipate these advances. Here we report the results from a large survey of machine learning researchers on their beliefs about progress in AI. Researchers predict AI will outperform humans in many activities in the next ten years, such as translating languages (by 2024), writing high-school essays (by 2026), driving a truck (by 2027), working in retail (by 2031), writing a bestselling book (by 2049), and working as a surgeon (by 2053). Researchers believe there is a $50 \%$ chance of AI outperforming humans in all tasks in 45 years and of automating all human jobs in 120 years, with Asian respondents expecting these dates much sooner than North Americans. These results will inform discussion amongst researchers and policymakers about anticipating and managing trends in AI.
\end{abstract}

\section{Introduction}

Advances in artificial intelligence (AI) will have massive social consequences. Self-driving technology might replace millions of driving jobs over the coming decade. In addition to possible unemployment, the transition will bring new challenges, such as rebuilding infrastructure, protecting vehicle cyber-security, and adapting laws and regulations (Calo, 2015). New challenges, both for AI developers and policy-makers, will also arise from applications in law enforcement, military technology, and marketing (Jiang, Petrovic, Ayyer, Tolani, \& Husain, 2015). To prepare for these challenges, accurate forecasting of transformative AI would be invaluable.

Several sources provide objective evidence about future AI advances: trends in computing hardware (Nordhaus, 2007), task performance (Grace, 2013), and the automation of labor (Brynjolfsson \& McAfee, 2012). The predictions of AI experts provide crucial additional information (Baum, Goertzel, \& Goertzel, 2011; Müller \& Bostrom, 2016; Walsh, 2017). We survey a large, representative sample of AI experts. Our questions cover the timing of AI advances (including both practical applications of AI and the automation of various human jobs), as well as the social and ethical impacts of AI. 


\section{Survey Method}

Our survey population was all researchers who published at the 2015 NIPS and ICML conferences (two of the premier venues for peer-reviewed research in machine learning). A total of 352 researchers responded to our survey invitation (21\% of the 1634 authors we contacted). Our questions concerned the timing of specific AI capabilities (e.g. folding laundry, language translation), superiority at specific occupations (e.g. truck driver, surgeon), superiority over humans at all tasks, and the social impacts of advanced AI. See Section 7 for details.
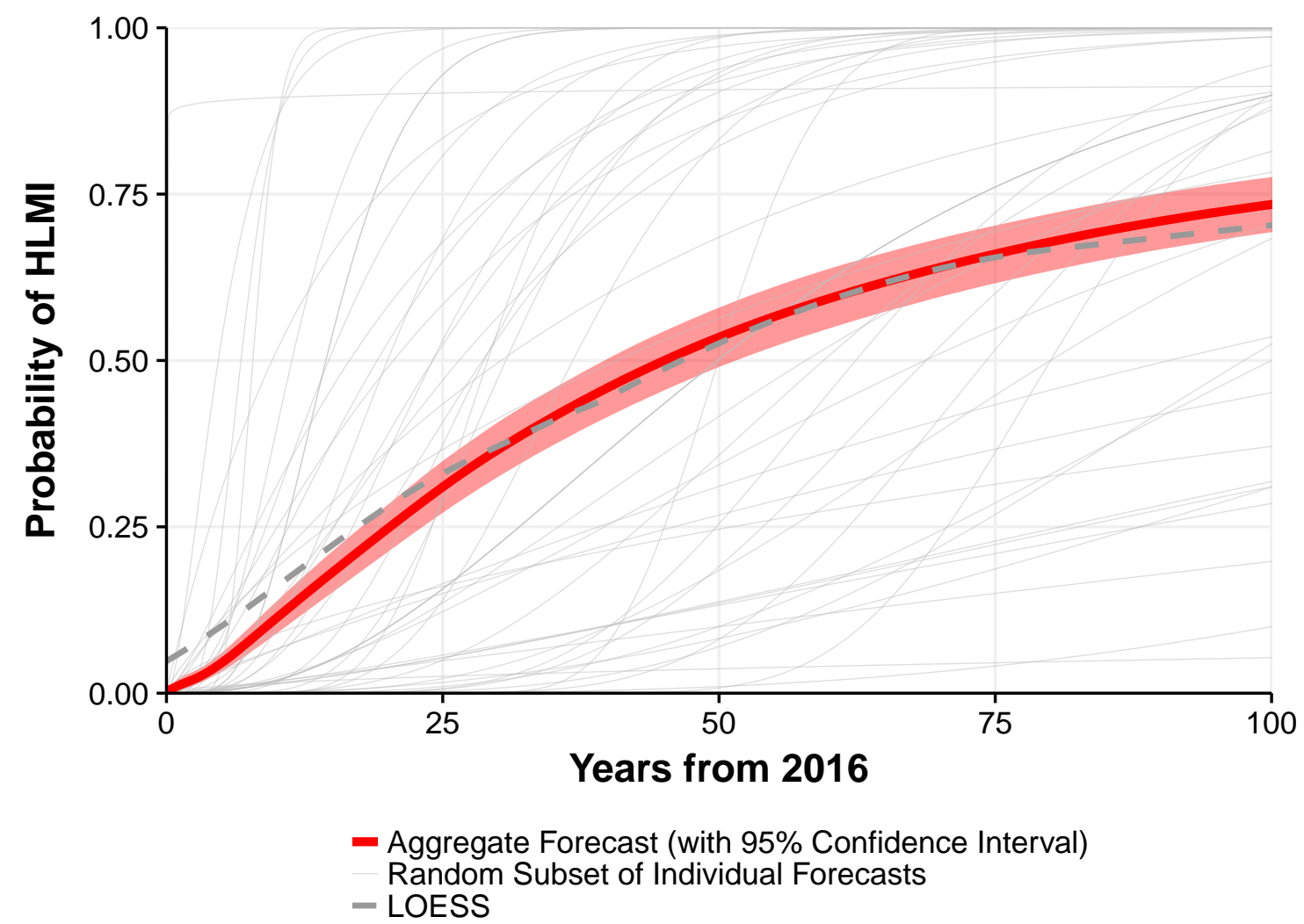

Figure 1: Aggregate subjective probability of 'high-level machine intelligence' arrival by future years. Each respondent provided three data points for their forecast and these were fit to the Gamma CDF by least squares to produce the grey CDFs. The "Aggregate Forecast" is the mean distribution over all individual CDFs (also called the "mixture" distribution). The confidence interval was generated by bootstrapping (clustering on respondents) and plotting the $95 \%$ interval for estimated probabilities at each year. The LOESS curve is a non-parametric regression on all data points.

\section{Time Until Machines Outperform Humans}

AI would have profound social consequences if all tasks were more cost effectively accomplished by machines. Our survey used the following definition: 
"High-level machine intelligence" (HLMI) is achieved when unaided machines can accomplish every task better and more cheaply than human workers.

Each individual respondent estimated the probability of HLMI arriving in future years. Taking the mean over each individual, the aggregate forecast gave a $50 \%$ chance of HLMI occurring within 45 years and a 10\% chance of it occurring within 9 years. Figure 1 displays the probabilistic predictions for a random subset of individuals, as well as the mean predictions. There is large inter-subject variation: Figure 3 shows that Asian respondents expect HLMI in 30 years, whereas North Americans expect it in 74 years.

While most participants were asked about HLMI, a subset were asked a logically similar question that emphasized consequences for employment. The question defined full automation of labor as:

when all occupations are fully automatable. That is, when for any occupation, machines could be built to carry out the task better and more cheaply than human workers.

Forecasts for full automation of labor were much later than for HLMI: the mean of the individual beliefs assigned a $50 \%$ probability in 122 years from now and a $10 \%$ probability in 20 years.

Respondents were also asked when 32 "milestones" for AI would become feasible. The full descriptions of the milestone are in Table C.5. Each milestone was considered by a random subset of respondents $(\mathrm{n} \geq 24)$. Respondents expected (mean probability of $50 \%) 20$ of the 32 AI milestones to be reached within ten years. Fig. 2 displays timelines for a subset of milestones.

\section{Intelligence Explosion, Outcomes, AI Safety}

The prospect of advances in AI raises important questions. Will progress in AI become explosively fast once AI research and development itself can be automated? How will highlevel machine intelligence (HLMI) affect economic growth? What are the chances this will lead to extreme outcomes (either positive or negative)? What should be done to help ensure AI progress is beneficial? Table C.4 displays results for questions we asked on these topics. Here are some key findings:

1. Researchers believe the field of machine learning has accelerated in recent years. We asked researchers whether the rate of progress in machine learning was faster in the first or second half of their career. Sixty-seven percent $(67 \%)$ said progress was faster in the second half of their career and only $10 \%$ said progress was faster in the first half. The median career length among respondents was 6 years.

2. Explosive progress in AI after HLMI is seen as possible but improbable. Some authors have argued that once HLMI is achieved, AI systems will quickly become vastly superior to humans in all tasks (Bostrom, 2014; Good, 1966). This acceleration has been called the "intelligence explosion." We asked respondents for the probability that AI would perform vastly better than humans in all tasks two years after HLMI 


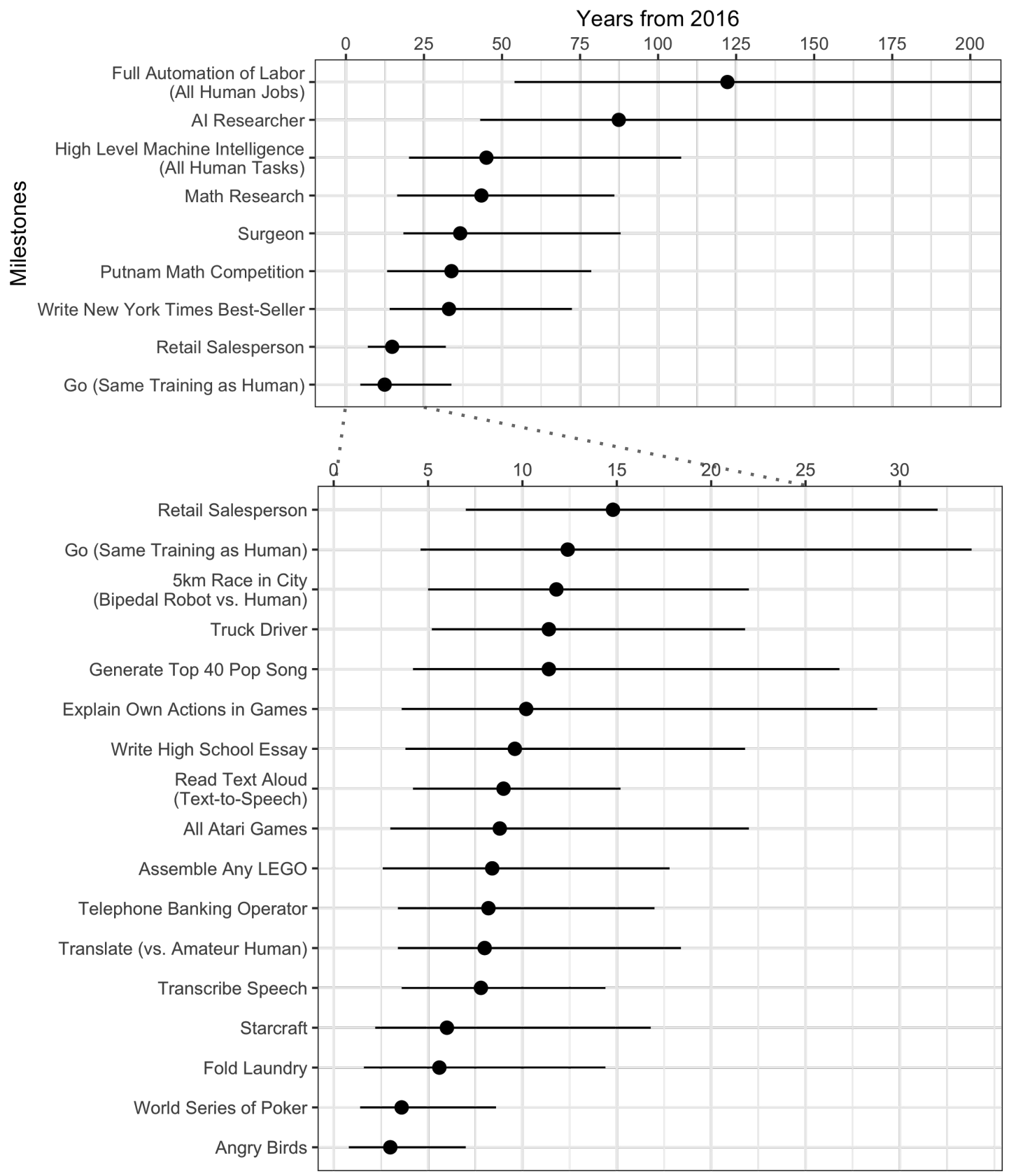

Figure 2: Timeline of Median Estimates (with 50\% intervals) for AI Achieving Human Performance. Timelines showing $50 \%$ probability intervals for achieving selected AI milestones. Specifically, intervals represent the date range from the $25 \%$ to $75 \%$ probability of the event occurring, calculated from the mean of individual CDFs as in Fig. 1. Circles denote the $50 \%$-probability year. Each milestone is for AI to achieve or surpass human expert/professional performance (full descriptions in Table C.5). Note that these intervals represent the uncertainty of survey respondents, not estimation uncertainty. 
is achieved. The median probability was $10 \%$ (interquartile range: 1-25\%). We also asked respondents for the probability of explosive global technological improvement two years after HLMI. Here the median probability was $20 \%$ (interquartile range 5$50 \%)$.

3. HLMI is seen as likely to have positive outcomes but catastrophic risks are possible. Respondents were asked whether HLMI would have a positive or negative impact on humanity over the long run. They assigned probabilities to outcomes on a five-point scale. The median probability was $25 \%$ for a "good" outcome and $20 \%$ for an "extremely good" outcome. By contrast, the probability was $10 \%$ for a bad outcome and 5\% for an outcome described as "Extremely Bad (e.g., human extinction)."

4. Society should prioritize research aimed at minimizing the potential risks of AI. Forty-eight percent of respondents think that research on minimizing the risks of AI should be prioritized by society more than the status quo (with only $12 \%$ wishing for less).

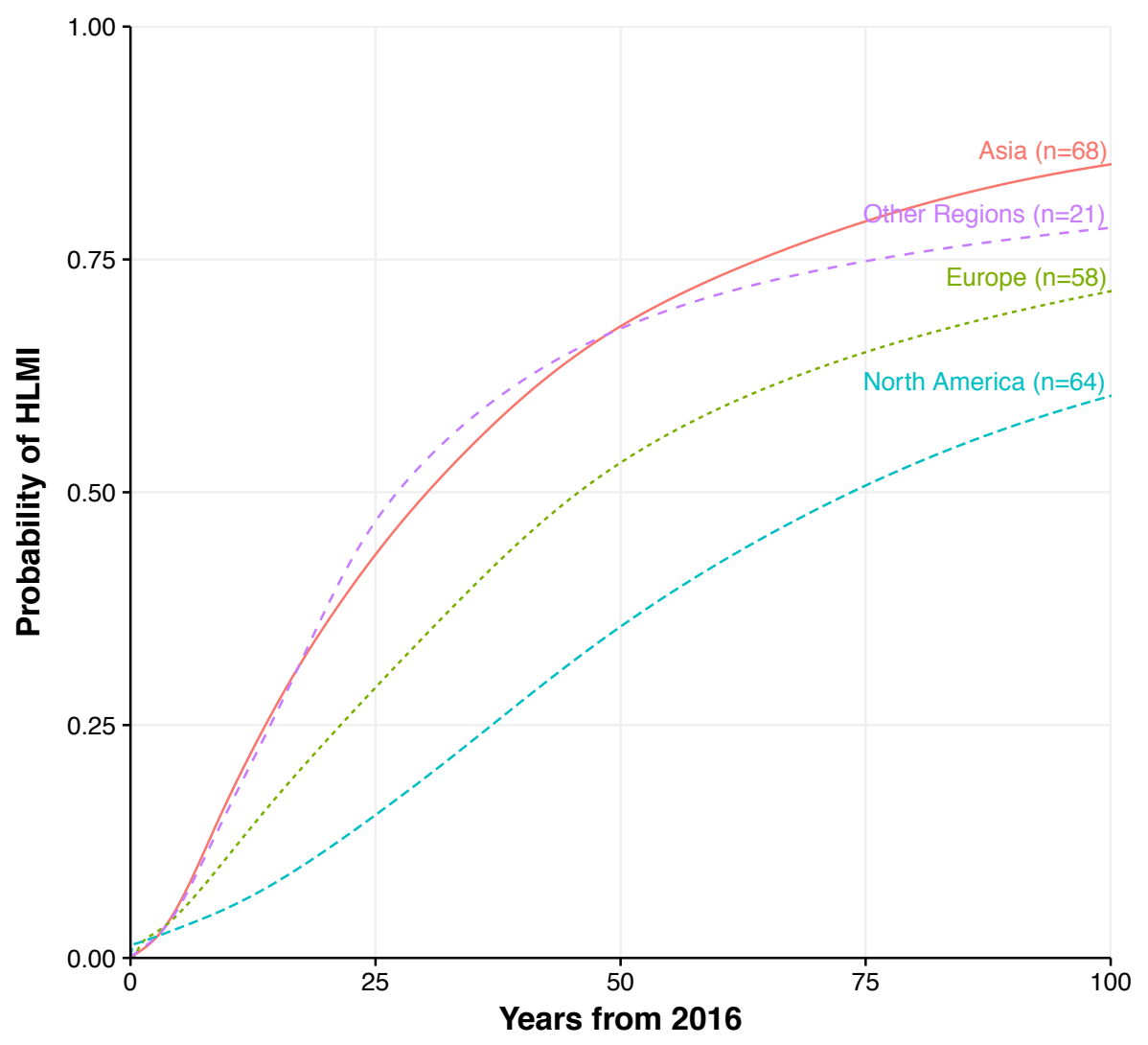

Figure 3: Aggregate Forecast (computed as in Figure 1) for HLMI, grouped by region in which respondent was an undergraduate. Additional regions (Middle East, S. America, Africa, Oceania) had much smaller numbers and are grouped as "Other Regions." 


\section{Asians Expect HLMI 44 Years Before North Americans}

Figure 3 shows big differences between individual respondents in when they predict HLMI will arrive. Both citation count and seniority were not predictive of HLMI timelines (see Fig. B.1 and the results of a regression in Table C.2). However, respondents from different regions had striking differences in HLMI predictions. Fig. 3 shows an aggregate prediction for HLMI of 30 years for Asian respondents and 74 years for North Americans. Fig. B.1 displays a similar gap between the two countries with the most respondents in the survey: China (median 28 years) and USA (median 76 years). Similarly, the aggregate year for a $50 \%$ probability for automation of each job we asked about (including truck driver and surgeon) was predicted to be earlier by Asians than by North Americans (Table C.2). Note that we used respondents' undergraduate institution as a proxy for country of origin and that many Asian respondents now study or work outside Asia.

\section{Was Our Sample Representative?}

One concern with any kind of survey is non-response bias; in particular, researchers with strong views may be more likely to fill out a survey. We tried to mitigate this effect by making the survey short (12 minutes) and confidential, and by not mentioning the survey's content or goals in our invitation email. Our response rate was $21 \%$. To investigate possible non-response bias, we collected demographic data for both our respondents $(n=406)$ and a random sample $(\mathrm{n}=399)$ of NIPS/ICML researchers who did not respond. Results are shown in Table C.3. Differences between the groups in citation count, seniority, gender, and country of origin are small. While we cannot rule out non-response biases due to unmeasured variables, we can rule out large bias due to the demographic variables we measured. Our demographic data also shows that our respondents included many highly-cited researchers (mostly in machine learning but also in statistics, computer science theory, and neuroscience) and came from 43 countries (vs. a total of 52 for everyone we sampled). A majority work in academia (82\%), while $21 \%$ work in industry.

A second concern is that NIPS and ICML authors are representative of machine learning but not of the field of artificial intelligence as a whole. This concern could be addressed in future work by surveying a broader range of experts across computer science, robotics, and the cognitive sciences. In fact, a 2017 survey by Walsh (2017) asked a broad range of AI and robotics experts a question about HLMI almost identical to ours. For a $50 \%$ chance of HLMI, the median prediction in this survey was 2065 for roboticists and 2061 for AI experts. Our machine learning experts predicted 2057. This is very close to Walsh's results and suggests that our conclusions about expert views on HLMI are robust to surveying experts outside machine learning. ${ }^{1}$ It's still possible that groups of experts differ on topics other than HLMI timelines.

1. The difference in medians between us and Walsh is tiny compared to differences between Asians and North Americans in our study and does not provide evidence of a substantial difference between groups of experts. 


\section{Discussion}

Why think AI experts have any ability to foresee AI progress? In the domain of political science, a long-term study found that experts were worse than crude statistical extrapolations at predicting political outcomes (Tetlock, 2005). AI progress, which relies on scientific breakthroughs, may appear intrinsically harder to predict. Yet there are reasons for optimism. While individual breakthroughs are unpredictable, longer term progress in R\&D for many domains (including computer hardware, genomics, solar energy) has been impressively regular (Farmer \& Lafond, 2016). Such regularity is also displayed by trends (Grace, 2013) in AI performance in SAT problem solving, games-playing, and computer vision and could be exploited by AI experts in their predictions. Finally, it is well established that aggregating individual predictions can lead to big improvements over the predictions of a random individual (Ungar et al., 2012). Further work could use our data to make optimized

forecasts. Moreover, many of the AI milestones (Fig. 2) were forecast to be achieved in the next decade, providing ground-truth evidence about the reliability of individual experts.

\section{Acknowledgments}

We thank Connor Flexman for collecting demographic information. We also thank Nick Bostrom for inspiring this work, and Michael Webb and Andreas Stuhlmüller for helpful comments. We thank the Future of Humanity Institute (Oxford), the Future of Life Institute, and the Open Philanthropy Project for supporting this work.

\section{Appendix A: Supplementary Information}

This supplement contains detailed information about the content of our survey and figures and tables showing additional results.

\section{A.1. Survey Content}

We developed questions through a series of interviews with Machine Learning researchers. Our survey questions were as follows:

1. Three sets of questions eliciting HLMI predictions by different framings: asking directly about HLMI, asking about the automatability of all human occupations, and asking about recent progress in AI from which we might extrapolate.

2. Three questions about the probability of an "intelligence explosion".

3. One question about the welfare implications of HLMI.

4. A set of questions about the effect of different inputs on the rate of AI research (e.g., hardware progress).

5. Two questions about sources of disagreement about AI timelines and "AI Safety".

6. Thirty-two questions about when AI will achieve narrow "milestones". 
7. Two sets of questions on AI Safety research: one about AI systems with non-aligned goals, and one on the prioritization of Safety research in general.

8. A set of demographic questions, including ones about how much thought respondents have given to these topics in the past. The questions were asked via an online Qualtrics survey. (The Qualtrics file will be shared to enable replication.) Participants were invited by email and were offered a financial reward for completing the survey. Questions were asked in roughly the order above and respondents received a randomized subset of questions. Surveys were completed between May 3rd 2016 and June 28th 2016.

Our goal in defining "high-level machine intelligence" (HLMI) was to capture the widelydiscussed notions of "human-level AI" or "general AI" (which contrasts with "narrow AI") (Bostrom, 2014). We consulted all previous surveys of AI experts and based our definition on that of an earlier survey (Müller \& Bostrom, 2016). Their definition of HLMI was a machine that "can carry out most human professions at least as well as a typical human." Our definition is more demanding and requires machines to be better at all tasks than humans (while also being more cost-effective). Since earlier surveys often use less demanding notions of HLMI, they should (all other things being equal) predict earlier arrival for HLMI.

\section{A.2. Demographic Information}

The demographic information on respondents and non-respondents (Table C.3) was collected from public sources, such as academic websites, LinkedIn profiles, and Google Scholar profiles. Citation count and seniority (i.e. numbers of years since the start of $\mathrm{PhD}$ ) were collected in February 2017.

\section{A.3. Statistics}

For each timeline probability question (see Figures 1 and 2), we computed an aggregate distribution by fitting a gamma CDF to each individual's responses using least squares and then taking the mixture distribution of all individuals. Reported medians and quantiles were computed on this summary distribution. The confidence intervals were generated by bootstrapping (clustering on respondents with 10,000 draws) and plotting the $95 \%$ interval for estimated probabilities at each year. The time-in-field and citations comparisons between respondents and non-respondents (Table C.3) were done using two-tailed t-tests. The region and gender proportions were done using two-sided proportion tests. The significance test for the effect of region on HLMI date (Table C.2) was done using robust linear regression using the $\mathrm{R}$ function $\mathrm{rlm}$ from the MASS package to do the regression and then the $\mathrm{f}$.robtest function from the sfsmisc package to do a robust F-test significance.

\section{A.4. Elicitation of Beliefs}

Many of our questions ask when an event will happen. For prediction tasks, ideal Bayesian agents provide a cumulative distribution function (CDF) from time to the cumulative probability of the event. When eliciting points on respondents' CDFs, we framed questions in two different ways, which we call "fixed-probability" and "fixed-years". Fixed-probability 
questions ask by which year an event has an $\mathrm{p} \%$ cumulative probability (for $\mathrm{p}=10 \%, 50 \%$, $90 \%$ ). Fixed-year questions ask for the cumulative probability of the event by year y (for $\mathrm{y}=10,25,50)$. The former framing was used in recent surveys of HLMI timelines; the latter framing is used in the psychological literature on forecasting (Tidwell, Wallsten, \& Moore, 2013; Wallsten, Shlomi, Nataf, \& Tomlinson, 2016). With a limited question budget, the two framings will sample different points on the CDF; otherwise, they are logically equivalent. Yet our survey respondents do not treat them as logically equivalent. We observed effects of question framing in all our prediction questions, as well as in pilot studies. Differences in these two framings have previously been documented in the forecasting literature (Tidwell et al., 2013; Wallsten et al., 2016) but there is no clear guidance on which framing leads to more accurate predictions. Thus we simply average over the two framings when computing CDF estimates for HLMI and for tasks. HLMI predictions for each framing are shown in Fig. B.2. 


\section{Appendix B: Supplementary Figures}

(a) Top 4 Undergraduate Country HLMI CDFs

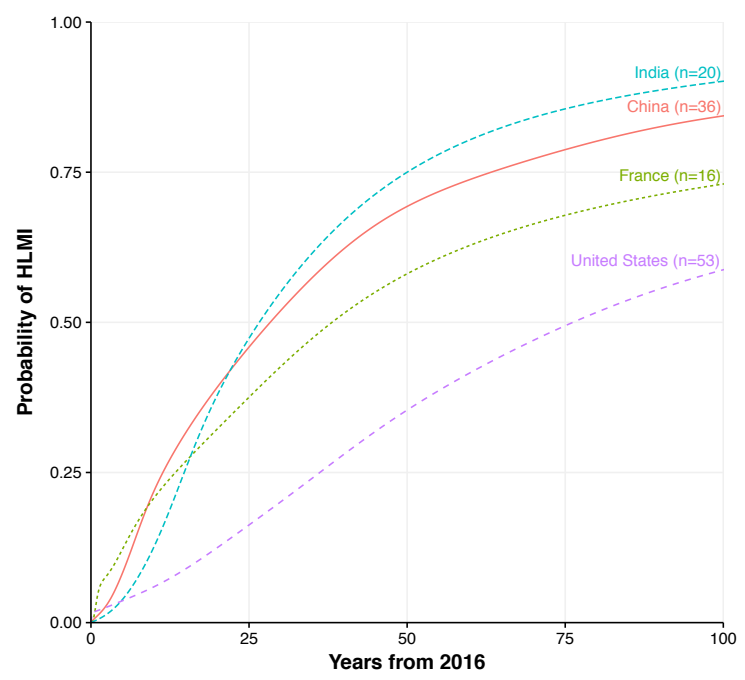

(b) Time in Field Quantile HLMI CDFs

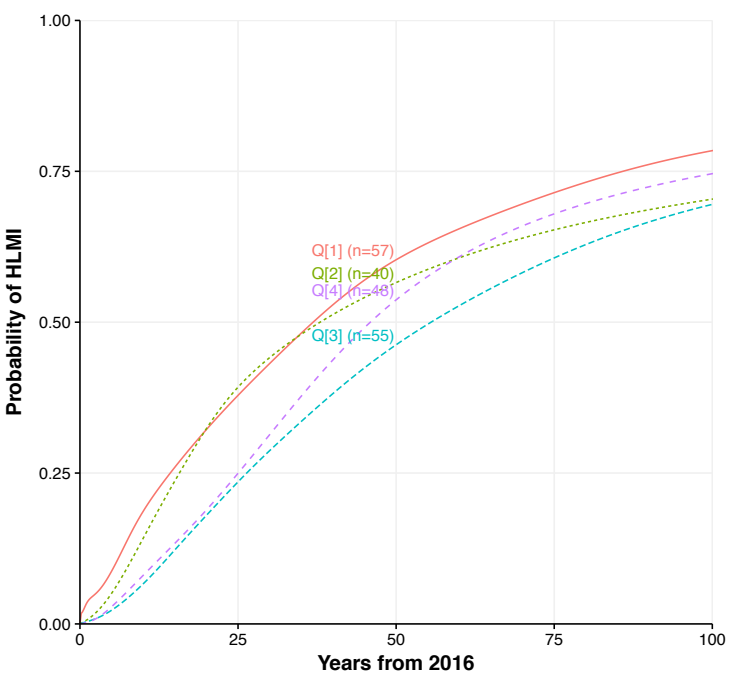

(c) Citation Count Quartile HLMI CDFs

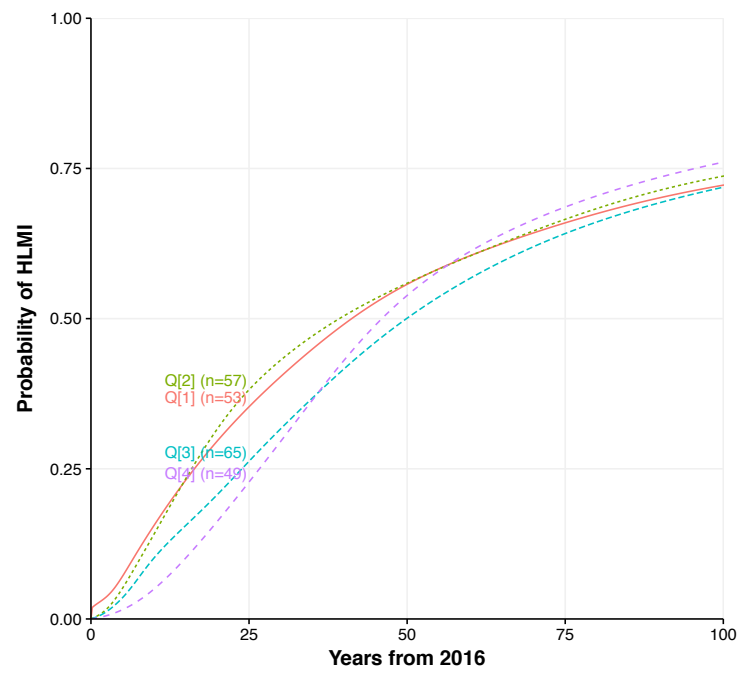

Figure B.1: Aggregate subjective probability of HLMI arrival by demographic group. Each graph curve is an Aggregate Forecasts CDF, computed using the procedure described in Figure 1 and in "Elicitation of Beliefs." Figure B.1a shows aggregate HLMI predictions for the four countries with the most respondents in our survey. Figure B.1b shows predictions grouped by quartiles for seniority (measured by time since they started a PhD). Figure B.1c shows predictions grouped by quartiles for citation count. "Q4" indicates the top quartile (i.e. the most senior researchers or the researchers with most citations). 
Framing CDFs

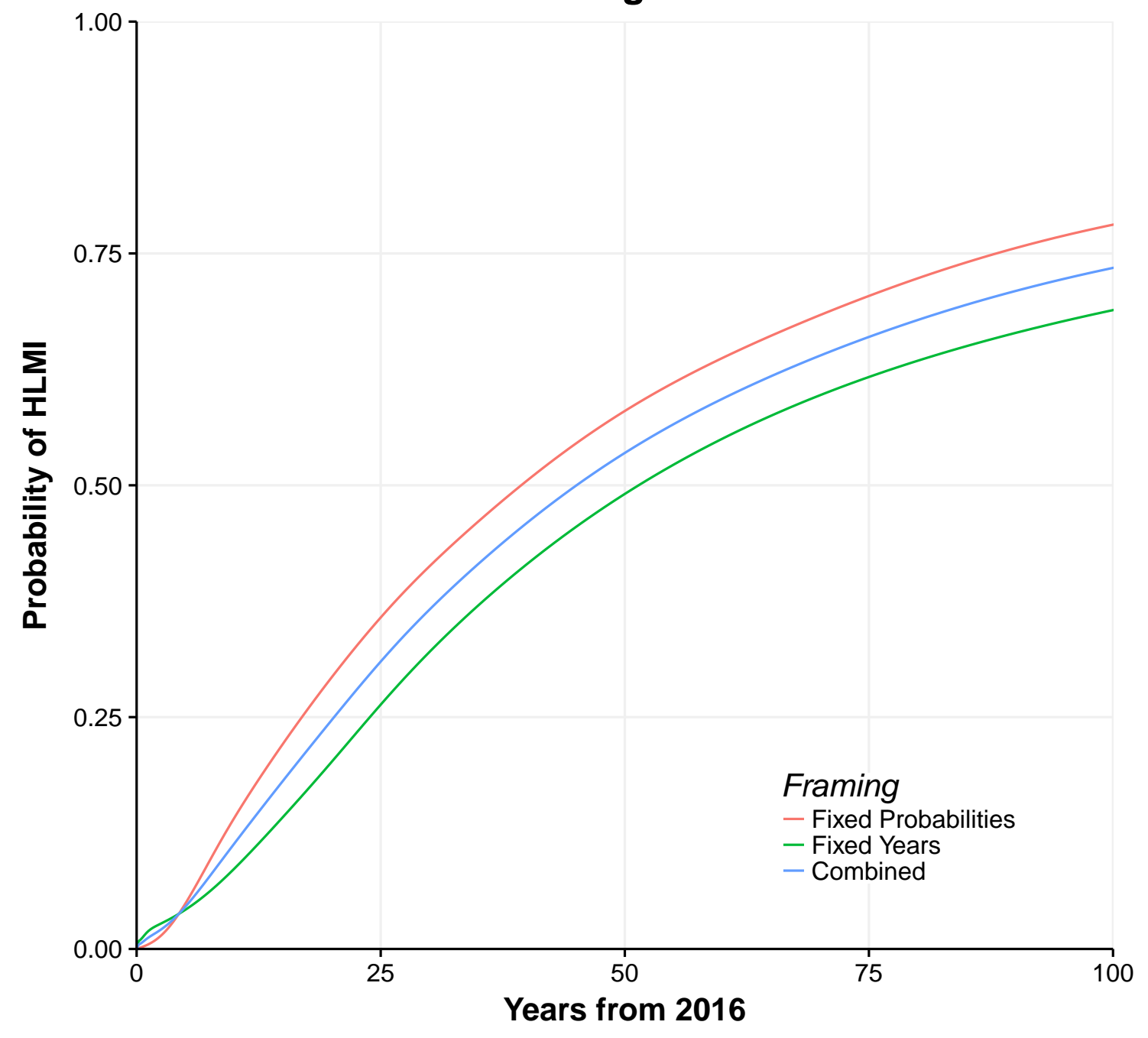

Figure B.2: Aggregate subjective probability of HLMI arrival for two framings of the question. The "fixed probabilities" and "fixed years" curves are each an aggregate forecast for HLMI predictions, computed using the same procedure as in Fig. 1. These two framings of questions about HLMI are explained in "Elicitation of Beliefs" (Section A.4). The "combined" curve is an average over these two framings and is the curve used in Fig. 1. 


\section{Appendix C: Supplementary Tables}

\section{C.1. Automation Predictions by Researcher Region}

This question asked when automation of the job would become feasible, and cumulative probabilities were elicited as in the HLMI and milestone prediction questions. The definition of "full automation" is given in Section 3. For the "NA/Asia gap", we subtract the Asian from the N. American median estimates.

Table C.1: Median estimate (in years from 2016) for automation of human jobs by region of undergraduate institution

\begin{tabular}{|l|l|l|l|l|}
\hline Question & Europe & N. America & Asia & NA/Asia gap \\
\hline Full Automation & 130.8 & 168.6 & 104.2 & +64.4 \\
\hline Truck Driver & 13.2 & 10.6 & 10.2 & +0.4 \\
\hline Surgeon & 46.4 & 41.0 & 31.4 & +9.6 \\
\hline Retail Salesperson & 18.8 & 20.2 & 10.0 & +10.2 \\
\hline AI Researcher & 80.0 & 123.6 & 109.0 & +14.6 \\
\hline
\end{tabular}

\section{C.2. Regression of HLMI Prediction on Demographic Features}

We standardized inputs and regressed the log of the median years until HLMI for respondents on gender, log of citations, seniority (i.e. numbers of years since start of $\mathrm{PhD}$ ), question framing ("fixed-probability" vs. "fixed-years") and region where the individual was an undergraduate. We used a robust linear regression.

Table C.2: Robust linear regression for individual HLMI predictions

\begin{tabular}{|l|l|l|l|l|l|}
\hline Term & Estimate & SE & $\boldsymbol{t}$-statistic & $\boldsymbol{p}$-value & $\begin{array}{l}\text { Wald } \\
\boldsymbol{F} \text { - } \\
\text { statistic }\end{array}$ \\
\hline (Intercept) & 3.65038 & 0.17320 & 21.07635 & 0.00000 & 458.0979 \\
\hline Gender = "female" & -0.25473 & 0.39445 & -0.64578 & 0.55320 & 0.3529552 \\
\hline log(citation_count) & -0.10303 & 0.13286 & -0.77546 & 0.44722 & 0.5802456 \\
\hline Seniority (years) & 0.09651 & 0.13090 & 0.73728 & 0.46689 & 0.5316029 \\
\hline Framing = "fixed_probs" & -0.34076 & 0.16811 & -2.02704 & 0.04414 & 4.109484 \\
\hline Region = "Europe" & 0.51848 & 0.21523 & 2.40898 & 0.01582 & 5.93565 \\
\hline Region = "M.East" & -0.22763 & 0.37091 & -0.61369 & 0.54430 & 0.3690532 \\
\hline Region = "N.America" & 1.04974 & 0.20849 & 5.03496 & 0.00000 & 25.32004 \\
\hline Region = "Other" & -0.26700 & 0.58311 & -0.45788 & 0.63278 & 0.2291022 \\
\hline
\end{tabular}




\section{C.3. Demographics of Respondents vs. Non-respondents}

There were $(n=406)$ respondents and $(n=399)$ non-respondents. Non-respondents were randomly sampled from all NIPS/ICML authors who did not respond to our survey invitation. Subjects with missing data for region of undergraduate institution or for gender are grouped in "NA". Missing data for citations and seniority is ignored in computing averages. Statistical tests are explained in the section "Statistics" (Section A.3).

Table C.3: Demographic differences between respondents and non-respondents

\begin{tabular}{|l|l|l|l|}
\hline $\begin{array}{l}\text { Undergraduate } \\
\text { region }\end{array}$ & $\begin{array}{l}\text { Respondent } \\
\text { proportion }\end{array}$ & $\begin{array}{l}\text { Non- } \\
\text { respondent } \\
\text { proportion }\end{array}$ & p-test $\boldsymbol{p}$-value \\
\hline Asia & 0.305 & 0.343 & 0.283 \\
\hline Europe & 0.271 & 0.236 & 0.284 \\
\hline Middle East & 0.071 & 0.063 & 0.721 \\
\hline North America & 0.254 & 0.221 & 0.307 \\
\hline Other & 0.015 & 0.013 & 1.000 \\
\hline NA & 0.084 & 0.125 & 0.070 \\
\hline
\end{tabular}

\begin{tabular}{|l|l|l|l|}
\hline Gender & $\begin{array}{l}\text { Respondent } \\
\text { proportion }\end{array}$ & $\begin{array}{l}\text { Non- } \\
\text { respondent } \\
\text { proportion }\end{array}$ & p-test $\boldsymbol{p}$-value \\
\hline female & 0.054 & 0.100 & 0.020 \\
\hline male & 0.919 & 0.842 & 0.001 \\
\hline NA & 0.027 & 0.058 & 0.048 \\
\hline
\end{tabular}

\begin{tabular}{|l|l|l|l|l|}
\hline Variable & $\begin{array}{l}\text { Respondent es- } \\
\text { timate }\end{array}$ & $\begin{array}{l}\text { Non- } \\
\text { respondent } \\
\text { estimate }\end{array}$ & Statistic & $p$-value \\
\hline Citations & 2740.5 & 4528.0 & 2.55 & 0.010856 \\
\hline $\log$ (Citations) & 5.9 & 6.4 & 3.19 & 0.001490 \\
\hline Years in field & 8.6 & 11.1 & 4.04 & 0.000060 \\
\hline
\end{tabular}

\section{C.4. Survey Responses on AI Progress, Intelligence Explosions, and AI Safety}

Three of the questions in Table C.4 concern Stuart Russell's argument about highly advanced AI. An excerpt of the argument was included in the survey. The full argument can be found here: www.edge.org/conversation/the-myth-of-ai\#26015. 


\begin{tabular}{|c|c|c|c|c|c|}
\hline $\begin{array}{l}\text { Chance HLMI has positive or negative } \\
\text { long run impact on humanity } \\
\text { (median answers) }\end{array}$ & $\begin{array}{l}\text { Extremely good } \\
\qquad 20 \%\end{array}$ & $\begin{array}{c}\text { On balance } \\
\text { good } \\
25 \%\end{array}$ & $\begin{array}{l}\text { Neutral } \\
20 \%\end{array}$ & $\begin{array}{c}\begin{array}{c}\text { On balance } \\
\text { bad }\end{array} \\
10 \%\end{array}$ & $\begin{array}{c}\text { Extremely bad } \\
\text { (e.g human } \\
\text { extinction) } \\
\\
5 \%\end{array}$ \\
\hline Time until 'full automation of labor' & $\begin{array}{c}10 \% \text { chance } \\
50 \text { years }\end{array}$ & $\begin{array}{c}\mathbf{5 0} \% \text { chance } \\
100 \text { years }\end{array}$ & $\begin{array}{c}90 \% \text { chance } \\
200 \text { years }\end{array}$ & & \\
\hline $\begin{array}{l}\text { Progress faster in } 1 \text { st or } 2 \text { nd half of } \\
\text { your career? }\end{array}$ & $\begin{array}{c}\begin{array}{c}\text { First half } \\
\text { (decelerating) }\end{array} \\
11 \%\end{array}$ & $\begin{array}{c}\text { About equal } \\
\qquad 24 \%\end{array}$ & $\begin{array}{c}\text { Second half } \\
\text { (accelerating) } \\
65 \%\end{array}$ & & \\
\hline $\begin{array}{l}\text { Chance global technological progress } \\
\text { dramatically increases after HLMI }\end{array}$ & $\begin{array}{c}2 \text { years after } \\
20 \%\end{array}$ & $\begin{array}{l}30 \text { years after } \\
80 \%\end{array}$ & & & \\
\hline $\begin{array}{l}\text { Chance intelligence explosion } \\
\text { argument is broadly correct }\end{array}$ & $\begin{array}{c}\text { Quite likely } \\
\text { (81-100\%) } \\
12 \%\end{array}$ & $\begin{array}{l}\text { Likely } \\
(61-80 \%) \\
17 \%\end{array}$ & $\begin{array}{c}\text { About even } \\
\text { (41-60\%) } \\
21 \%\end{array}$ & $\begin{array}{l}\text { Unlikely } \\
\text { (21-40\%) } \\
24 \%\end{array}$ & $\begin{array}{l}\text { Quite unlikely } \\
\text { (0-20\%) } \\
26 \%\end{array}$ \\
\hline $\begin{array}{l}\text { Does Stuart Russell's argument for } \\
\text { why highly advanced Al might pose } \\
\text { a risk point at an important problem? }\end{array}$ & $\begin{array}{c}\text { No, not a real } \\
\text { problem. } \\
11 \%\end{array}$ & $\begin{array}{c}\begin{array}{c}\text { No, not an } \\
\text { important } \\
\text { problem. }\end{array} \\
19 \%\end{array}$ & $\begin{array}{c}\begin{array}{c}\text { Yes, a } \\
\text { moderately } \\
\text { important } \\
\text { problem. }\end{array} \\
31 \%\end{array}$ & $\begin{array}{c}\begin{array}{c}\text { Yes, an } \\
\text { important } \\
\text { problem. }\end{array} \\
34 \%\end{array}$ & $\begin{array}{c}\text { Yes, among the } \\
\text { most important } \\
\text { problems } \\
\text { in the field. } \\
5 \%\end{array}$ \\
\hline $\begin{array}{l}\text { Value of working on this problem now, } \\
\text { compared to other problems in the field }\end{array}$ & $\begin{array}{c}\text { Much less valuable } \\
22 \%\end{array}$ & $\begin{array}{l}\text { Less valuable } \\
\qquad 41 \%\end{array}$ & $\begin{array}{c}\text { As valuable } \\
\text { as other } \\
\text { problems } \\
28 \%\end{array}$ & $\begin{array}{l}\text { More valuable } \\
\quad 7 \%\end{array}$ & $\begin{array}{c}\begin{array}{c}\text { Much more } \\
\text { valuable }\end{array} \\
1.4 \%\end{array}$ \\
\hline $\begin{array}{l}\text { Difficulty of problem, relative to } \\
\text { other problems in the field }\end{array}$ & $\begin{array}{l}\text { Much easier } \\
\quad 7 \%\end{array}$ & $\begin{array}{c}\text { Easier } \\
19 \%\end{array}$ & $\begin{array}{c}\begin{array}{c}\text { As hard as } \\
\text { other problems }\end{array} \\
42 \%\end{array}$ & $\begin{array}{c}\text { Harder } \\
23 \%\end{array}$ & $\begin{array}{c}\text { Much harder } \\
10 \%\end{array}$ \\
\hline $\begin{array}{l}\text { How much should society prioritize } \\
\text { 'Al Safety Research'? } \\
\text { (included capabilities vs. } \\
\text { minimizing potential risks definition) }\end{array}$ & Much less & Less & $\begin{array}{l}\text { About the same } \\
\text { as it is now }\end{array}$ & More & Much more \\
\hline & Very little & A little & $\begin{array}{l}\text { A moderate } \\
\text { amount }\end{array}$ & A lot & A great deal \\
\hline $\begin{array}{l}\text { How much have you thought about whe } \\
\text { HLMI (or similar) will be developed? }\end{array}$ & $6 \%$ & $27 \%$ & $28 \%$ & $31 \%$ & $8 \%$ \\
\hline
\end{tabular}

Table C.4: Median survey responses for AI progress and safety questions 


\section{C.5. Description of AI Milestones}

The timelines in Figure 2 are based on respondents' predictions about the achievement of various milestones in AI. Beliefs were elicited in the same way as for HLMI predictions (see "Elicitation of Beliefs" above). We chose a subset of all milestones to display in Figure 2 based on which milestones could be accurately described with a short label.

Table C.5: Descriptions of AI Milestones

\begin{tabular}{|c|c|c|c|c|}
\hline Milestone Name & Description & $\mathbf{n}$ & In Fig. 2 & $\begin{array}{l}\text { median } \\
\text { (years) }\end{array}$ \\
\hline $\begin{array}{l}\text { Translate New Language } \\
\text { with 'Rosetta Stone' }\end{array}$ & $\begin{array}{l}\text { Translate a text written } \\
\text { in a newly discovered lan- } \\
\text { guage into English as well } \\
\text { as a team of human ex- } \\
\text { perts, using a single other } \\
\text { document in both lan- } \\
\text { guages (like a Rosetta } \\
\text { stone). Suppose all of } \\
\text { the words in the text can } \\
\text { be found in the translated } \\
\text { document, and that the } \\
\text { language is a difficult one. }\end{array}$ & 35 & & 16.6 \\
\hline $\begin{array}{l}\text { Translate Speech Based on } \\
\text { Subtitles }\end{array}$ & $\begin{array}{l}\text { Translate speech in a new } \\
\text { language given only unlim- } \\
\text { ited films with subtitles in } \\
\text { the new language. Sup- } \\
\text { pose the system has access } \\
\text { to training data for other } \\
\text { languages, of the kind used } \\
\text { now (e.g., same text in two } \\
\text { languages for many lan- } \\
\text { guages and films with sub- } \\
\text { titles in many languages). }\end{array}$ & 38 & & 10 \\
\hline $\begin{array}{l}\text { Translate (vs. amateur hu- } \\
\text { man) }\end{array}$ & $\begin{array}{l}\text { Perform translation about } \\
\text { as good as a human who } \\
\text { is fluent in both languages } \\
\text { but unskilled at transla- } \\
\text { tion, for most types of } \\
\text { text, and for most pop- } \\
\text { ular languages (including } \\
\text { languages that are known } \\
\text { to be difficult, like Czech, } \\
\text { Chinese and Arabic). }\end{array}$ & 42 & $\mathrm{X}$ & 8 \\
\hline
\end{tabular}




\begin{tabular}{|l|l|l|l|l|}
\hline Telephone Banking Opera- & $\begin{array}{l}\text { Provide phone banking } \\
\text { tor } \\
\text { services as well as human } \\
\text { operators can without } \\
\text { annoying customers more } \\
\text { than humans This in- } \\
\text { cludes many one-off tasks, } \\
\text { such as helping to order a } \\
\text { replacement bank card or } \\
\text { clarifying how to use part } \\
\text { of the bank website to a } \\
\text { customer. }\end{array}$ & 8.2 \\
\hline Make Novel Categories & $\begin{array}{l}\text { Correctly group images of } \\
\text { previously unseen objects } \\
\text { into classes, after training } \\
\text { on a similar labeled dataset } \\
\text { containing completely dif- } \\
\text { ferent classes. The classes } \\
\text { should be similar to the Im- } \\
\text { ageNet classes. }\end{array}$ & 29 \\
\hline
\end{tabular}




\begin{tabular}{|c|c|c|c|}
\hline One-Shot Learning & $\begin{array}{l}\text { One-shot learning: see only } \\
\text { one labeled image of a new } \\
\text { object, and then be able } \\
\text { to recognize the object in } \\
\text { real world scenes, to the } \\
\text { extent that a typical hu- } \\
\text { man can (i.e. including in } \\
\text { a wide variety of settings). } \\
\text { For example, see only one } \\
\text { image of a platypus, and } \\
\text { then be able to recognize } \\
\text { platypuses in nature pho- } \\
\text { tos. The system may train } \\
\text { on labeled images of other } \\
\text { objects. } \\
\text { Currently, deep networks } \\
\text { often need hundreds of } \\
\text { examples in classification } \\
\text { tasks[1], but there has been } \\
\text { work on one-shot learning } \\
\text { for both classification[2] } \\
\text { and generative tasks[3]. } \\
\text { [1] Lake et al. (2015). } \\
\text { Building Machines That } \\
\text { Learn and Think Like Peo- } \\
\text { ple } \\
\text { [2] Koch (2015) Siamese } \\
\text { Neural Networks for One- } \\
\text { Shot Image Recognition } \\
\text { [3] Rezende et al. (2016). } \\
\text { One-Shot Generalization in } \\
\text { Deep Generative Models }\end{array}$ & 32 & 9.4 \\
\hline
\end{tabular}




\begin{tabular}{|c|c|c|c|c|}
\hline $\begin{array}{l}\text { Generate Video from New } \\
\text { Direction }\end{array}$ & $\begin{array}{l}\text { See a short video of a scene, } \\
\text { and then be able to con- } \\
\text { struct a 3D model of the } \\
\text { scene good enough to cre- } \\
\text { ate a realistic video of the } \\
\text { same scene from a substan- } \\
\text { tially different angle. } \\
\text { For example, constructing } \\
\text { a short video of walking } \\
\text { through a house from a } \\
\text { video taking a very dif- } \\
\text { ferent path through the } \\
\text { house. }\end{array}$ & 42 & & 11.6 \\
\hline Transcribe Speech & $\begin{array}{l}\text { Transcribe human speech } \\
\text { with a variety of accents in } \\
\text { a noisy environment as well } \\
\text { as a typical human can. }\end{array}$ & 33 & $\bar{X}$ & 7.8 \\
\hline $\begin{array}{l}\text { Read Text Aloud (text-to- } \\
\text { spech) }\end{array}$ & $\begin{array}{l}\text { Take a written passage and } \\
\text { output a recording that } \\
\text { can't be distinguished from } \\
\text { a voice actor, by an expert } \\
\text { listener. }\end{array}$ & 43 & $\mathrm{X}$ & 9 \\
\hline Math Research & $\begin{array}{l}\text { Routinely and au- } \\
\text { tonomously prove mathe- } \\
\text { matical theorems that are } \\
\text { publishable in top math- } \\
\text { ematics journals today, } \\
\text { including generating the } \\
\text { theorems to prove. }\end{array}$ & 31 & $\mathrm{X}$ & 43.4 \\
\hline $\begin{array}{l}\text { Putnam Math Competi- } \\
\text { tion }\end{array}$ & $\begin{array}{l}\text { Perform as well as the } \\
\text { best human entrants in the } \\
\text { Putnam competition-a } \\
\text { math contest whose } \\
\text { questions have known } \\
\text { solutions, but which are } \\
\text { difficult for the best young } \\
\text { mathematicians. }\end{array}$ & 45 & $\mathrm{X}$ & 33.8 \\
\hline
\end{tabular}




\begin{tabular}{|c|c|c|c|c|}
\hline $\begin{array}{l}\text { Go (same training as hu- } \\
\text { man) }\end{array}$ & $\begin{array}{l}\text { Defeat the best Go players, } \\
\text { training only on as many } \\
\text { games as the best Go play- } \\
\text { ers have played. } \\
\text { For reference, DeepMind's } \\
\text { AlphaGo has probably } \\
\text { played a hundred million } \\
\text { games of self-play, while } \\
\text { Lee Sedol has probably } \\
\text { played } 50,000 \text { games in his } \\
\text { life[1]. } \\
\text { [1] Lake et al. (2015). } \\
\text { Building Machines That } \\
\text { Learn and Think Like Peo- } \\
\text { ple }\end{array}$ & 42 & $\mathrm{X}$ & 17.6 \\
\hline Starcraft & $\begin{array}{l}\text { Beat the best human Star- } \\
\text { craft } 2 \text { players at least } 50 \\
\text { Starcraft } 2 \text { is a real time } \\
\text { strategy game character- } \\
\text { ized by: } \\
\text { - Continuous time play } \\
\text { - Huge action space } \\
\text { - Partial observability } \\
\text { of enemies } \\
\text { - Long term strategic } \\
\text { play, e.g. preparing } \\
\text { for and then hiding } \\
\text { surprise attacks. }\end{array}$ & 24 & $\mathrm{X}$ & 6 \\
\hline $\begin{array}{l}\text { Quick Novice Play at Ran- } \\
\text { dom Game }\end{array}$ & $\begin{array}{l}\text { Play a randomly selected } \\
\text { computer game, including } \\
\text { difficult ones, about as well } \\
\text { as a human novice, after } \\
\text { playing the game less than } \\
10 \text { minutes of game time. } \\
\text { The system may train on } \\
\text { other games. }\end{array}$ & 44 & & 12.4 \\
\hline
\end{tabular}




\begin{tabular}{|c|c|c|c|c|}
\hline Angry Birds & $\begin{array}{l}\text { Play new levels of An- } \\
\text { gry Birds better than the } \\
\text { best human players. Angry } \\
\text { Birds is a game where play- } \\
\text { ers try to efficiently destroy } \\
\text { 2D block towers with a cat- } \\
\text { apult. For context, this is } \\
\text { the goal of the IJCAI An- } \\
\text { gry Birds AI competition. }\end{array}$ & 39 & $\mathrm{X}$ & 3 \\
\hline All Atari Games & $\begin{array}{l}\text { Outperform professional } \\
\text { game testers on all Atari } \\
\text { games using no game- } \\
\text { specific knowledge. This } \\
\text { includes games like Frost- } \\
\text { bite, which require plan- } \\
\text { ning to achieve sub-goals } \\
\text { and have posed problems } \\
\text { for deep Q-networks[1][2]. } \\
\text { [1] Mnih et al. (2015). } \\
\text { Human-level control } \\
\text { through deep reinforce- } \\
\text { ment learning. } \\
{[2] \text { Lake et al. (2015). }} \\
\text { Building Machines That } \\
\text { Learn and Think Like Peo- } \\
\text { ple }\end{array}$ & 38 & $\mathrm{X}$ & 8.8 \\
\hline
\end{tabular}




\begin{tabular}{|c|c|c|c|c|}
\hline $\begin{array}{l}\text { Novice Play at half of Atari } \\
\text { Games in } 20 \text { Minutes }\end{array}$ & $\begin{array}{l}\text { Outperform human novices } \\
\text { on } 50 \% \text { of Atari games } \\
\text { after only } 20 \text { minutes of } \\
\text { training play time and no } \\
\text { game specific knowledge. } \\
\text { For context, the origi- } \\
\text { nal Atari playing deep Q- } \\
\text { network outperforms pro- } \\
\text { fessional game testers on } \\
47 \% \text { of games[1], but used } \\
\text { hundreds of hours of play } \\
\text { to train[2]. } \\
\text { [1] Mnih et al. (2015). } \\
\text { Human-level control } \\
\text { through deep reinforce- } \\
\text { ment learning. } \\
{[2] \text { Lake et al. (2015). }} \\
\text { Building Machines That } \\
\text { Learn and Think Like Peo- } \\
\text { ple }\end{array}$ & 33 & & 6.6 \\
\hline Fold Laundry & $\begin{array}{l}\text { Fold laundry as well and as } \\
\text { fast as the median human } \\
\text { clothing store employee. }\end{array}$ & 30 & $\mathrm{X}$ & 5.6 \\
\hline $\begin{array}{l}5 \mathrm{~km} \text { Race in City (bipedal } \\
\text { robot vs. human) }\end{array}$ & $\begin{array}{l}\text { Beat the fastest human } \\
\text { runners in a } 5 \text { kilometer } \\
\text { race through city streets } \\
\text { using a bipedal robot body. }\end{array}$ & 28 & $\mathrm{X}$ & 11.8 \\
\hline Assemble any LEGO & $\begin{array}{l}\text { Physically assemble any } \\
\text { LEGO set given the pieces } \\
\text { and instructions, using } \\
\text { non- specialized robotics } \\
\text { hardware. } \\
\text { For context, Fu 2016[1] } \\
\text { successfully joins single } \\
\text { large LEGO pieces using } \\
\text { model based reinforce- } \\
\text { ment learning and online } \\
\text { adaptation. } \\
\text { [1] Fu et al. (2016). One- } \\
\text { Shot Learning of Manip- } \\
\text { ulation Skills with Online } \\
\text { Dynamics Adaptation and } \\
\text { Neural Network Priors }\end{array}$ & 35 & $\mathrm{X}$ & 8.4 \\
\hline
\end{tabular}




\begin{tabular}{|c|c|c|c|}
\hline $\begin{array}{l}\text { Learn to Sort Big Numbers } \\
\text { Without Solution Form }\end{array}$ & $\begin{array}{l}\text { Learn to efficiently sort } \\
\text { lists of numbers much } \\
\text { larger than in any train- } \\
\text { ing set used, the way } \\
\text { Neural GPUs can do for } \\
\text { addition[1], but without } \\
\text { being given the form of the } \\
\text { solution. } \\
\text { For context, Neural Tur- } \\
\text { ing Machines have not } \\
\text { been able to do this[2], } \\
\text { but Neural Programmer- } \\
\text { Interpreters[3] have been } \\
\text { able to do this by train- } \\
\text { ing on stack traces (which } \\
\text { contain a lot of information } \\
\text { about the form of the solu- } \\
\text { tion). } \\
\text { [1] Kaiser \& Sutskever } \\
\text { (2015). Neural GPUs } \\
\text { Learn Algorithms } \\
\text { [2] Zaremba \& Sutskever } \\
\text { (2015). Reinforcement } \\
\text { Learning Neural Turing } \\
\text { Machines } \\
\text { [3] Reed \& de Fre- } \\
\text { itas (2015). Neural } \\
\text { Programmer-Interpreters }\end{array}$ & 44 & 6.2 \\
\hline
\end{tabular}




\begin{tabular}{|c|c|c|c|}
\hline $\begin{array}{l}\text { Python Code for Simple } \\
\text { Algorithms }\end{array}$ & $\begin{array}{l}\text { Write concise, efficient, } \\
\text { human-readable Python } \\
\text { code to implement simple } \\
\text { algorithms like quicksort. } \\
\text { That is, the system should } \\
\text { write code that sorts a list, } \\
\text { rather than just being able } \\
\text { to sort lists. } \\
\text { Suppose the system is } \\
\text { given only: } \\
\text { - A specification of } \\
\text { what counts as a } \\
\text { sorted list } \\
\text { - Several examples of } \\
\text { lists undergoing sort- } \\
\text { ing by quicksort }\end{array}$ & 36 & 8.2 \\
\hline $\begin{array}{l}\text { Answer Factoid Questions } \\
\text { via Internet }\end{array}$ & $\begin{array}{l}\text { Answer any "easily } \\
\text { Googleable" factoid ques- } \\
\text { tions posed in natural } \\
\text { language better than an } \\
\text { expert on the relevant } \\
\text { topic (with internet ac- } \\
\text { cess), having found the } \\
\text { answers on the internet. } \\
\text { Examples of factoid ques- } \\
\text { tions: } \\
\text { - "What is the poi- } \\
\text { sonous substance in } \\
\text { Oleander plants?" } \\
\text { - "How many species of } \\
\text { lizard can be found in } \\
\text { Great Britain?" }\end{array}$ & 46 & 7.2 \\
\hline
\end{tabular}




\begin{tabular}{|c|c|c|c|c|}
\hline $\begin{array}{l}\text { Answer Open-Ended Fac- } \\
\text { tual Questions via Internet }\end{array}$ & $\begin{array}{l}\text { Answer any "easily } \\
\text { Googleable" factual but } \\
\text { open ended question posed } \\
\text { in natural language better } \\
\text { than an expert on the rel- } \\
\text { evant topic (with internet } \\
\text { access), having found the } \\
\text { answers on the internet. } \\
\text { Examples of open ended } \\
\text { questions: } \\
\text { - "What does it mean } \\
\text { if my lights dim when } \\
\text { I turn on the mi- } \\
\text { crowave?" } \\
\text { - "When does home in- } \\
\text { surance cover roof re- } \\
\text { placement?" }\end{array}$ & 38 & & 9.8 \\
\hline $\begin{array}{l}\text { Answer Questions Without } \\
\text { Definite Answers }\end{array}$ & $\begin{array}{l}\text { Give good answers in nat- } \\
\text { ural language to factual } \\
\text { questions posed in natural } \\
\text { language for which there } \\
\text { are no definite correct an- } \\
\text { swers. } \\
\text { For example: "What causes } \\
\text { the demographic transi- } \\
\text { tion?", "Is the thylacine ex- } \\
\text { tinct?", "How safe is seeing } \\
\text { a chiropractor?" }\end{array}$ & 47 & & 10 \\
\hline High School Essay & $\begin{array}{l}\text { Write an essay for a high- } \\
\text { school history class that } \\
\text { would receive high grades } \\
\text { and pass plagiarism detec- } \\
\text { tors. } \\
\text { For example answer a ques- } \\
\text { tion like "How did the } \\
\text { whaling industry affect the } \\
\text { industrial revolution?" }\end{array}$ & 42 & $\mathrm{X}$ & 9.6 \\
\hline
\end{tabular}




\begin{tabular}{|c|c|c|c|c|}
\hline Generate Top 40 Pop Song & $\begin{array}{l}\text { Compose a song that is } \\
\text { good enough to reach the } \\
\text { US Top } 40 \text {. The system } \\
\text { should output the complete } \\
\text { song as an audio file. }\end{array}$ & 38 & $\mathrm{X}$ & 11.4 \\
\hline $\begin{array}{l}\text { Produce a Song Indistin- } \\
\text { guishable from One by a } \\
\text { Specific Artist }\end{array}$ & $\begin{array}{l}\text { Produce a song that is in- } \\
\text { distinguishable from a new } \\
\text { song by a particular artist, } \\
\text { e.g., a song that experi- } \\
\text { enced listeners can't distin- } \\
\text { guish from a new song by } \\
\text { Taylor Swift. }\end{array}$ & 41 & & 10.8 \\
\hline $\begin{array}{lll}\text { Write New } & \text { York } & \text { Times } \\
\text { Best-Seller } & & \end{array}$ & $\begin{array}{l}\text { Write a novel or short story } \\
\text { good enough to make it to } \\
\text { the New York Times best- } \\
\text { seller list. }\end{array}$ & 27 & $\mathrm{X}$ & 33 \\
\hline $\begin{array}{l}\text { Explain Own Actions in } \\
\text { Games }\end{array}$ & $\begin{array}{l}\text { For any computer game } \\
\text { that can be played well by } \\
\text { a machine, explain the ma- } \\
\text { chine's choice of moves in a } \\
\text { way that feels concise and } \\
\text { complete to a layman. }\end{array}$ & 38 & $\mathrm{X}$ & 10.2 \\
\hline World Series of Poker & $\begin{array}{l}\text { Play poker well enough to } \\
\text { win the World Series of } \\
\text { Poker. }\end{array}$ & 37 & $\mathrm{X}$ & 3.6 \\
\hline $\begin{array}{l}\text { Output Physical Laws of } \\
\text { Virtual World }\end{array}$ & $\begin{array}{l}\text { After spending time in a } \\
\text { virtual world, output the } \\
\text { differential equations gov- } \\
\text { erning that world in sym- } \\
\text { bolic form. } \\
\text { For example, the agent is } \\
\text { placed in a game engine } \\
\text { where Newtonian mechan- } \\
\text { ics holds exactly and the } \\
\text { agent is then able to con- } \\
\text { duct experiments with a } \\
\text { ball and output Newton's } \\
\text { laws of motion. }\end{array}$ & 52 & & 14.8 \\
\hline
\end{tabular}




\section{References}

Baum, S. D., Goertzel, B., \& Goertzel, T. G. (2011). How long until human-level ai? results from an expert assessment. Technological Forecasting and Social Change, 78(1), 185195.

Bostrom, N. (2014). Superintelligence: Paths, dangers, strategies. Oxford, UK: Oxford University Press.

Brynjolfsson, E., \& McAfee, A. (2012). Race against the machine: How the digital revolution is accelerating innovation, driving productivity, and irreversibly transforming employment and the economy. Lexington, MA: Digital Frontier Press.

Calo, R. (2015). Robotics and the lessons of cyberlaw. California Law Review, 103, 513.

Farmer, J. D., \& Lafond, F. (2016). How predictable is technological progress? Research Policy, 45(3), 647-665.

Good, I. J. (1966). Speculations concerning the first ultraintelligent machine. Advances in computers, 6 , 31-88.

Grace, K. (2013). Algorithmic progress in six domains (Tech. Rep.). Machine Intelligence Research Institute.

Jiang, T., Petrovic, S., Ayyer, U., Tolani, A., \& Husain, S. (2015). Self-driving cars: Disruptive or incremental. Applied Innovation Review, 1, 3-22.

Müller, V. C., \& Bostrom, N. (2016). Future progress in artificial intelligence: A survey of expert opinion. In V. C. Müller (Ed.), Fundamental issues of artificial intelligence (pp. 553-570). Springer.

Nordhaus, W. D. (2007). Two centuries of productivity growth in computing. The Journal of Economic History, 67(01), 128-159.

Tetlock, P. (2005). Expert political judgment: How good is it? how can we know? Princeton, NJ: Princeton University Press.

Tidwell, J. W., Wallsten, T. S., \& Moore, D. A. (2013). Eliciting and modeling probability forecasts of continuous quantities. (Paper presented at the 27th Annual Conference of Society for Judgement and Decision Making, Boston, MA, 19 November 2016.)

Ungar, L., Mellors, B., Satopää, V., Baron, J., Tetlock, P., Ramos, J., \& Swift, S. (2012). The good judgment project: A large scale test (Tech. Rep.). Association for the Advancement of Artificial Intelligence Technical Report.

Wallsten, T. S., Shlomi, Y., Nataf, C., \& Tomlinson, T. (2016). Efficiently encoding and modeling subjective probability distributions for quantitative variables. Decision, 3(3), 169.

Walsh, T. (2017). Expert and non-expert opinion about technological unemployment. arXiv preprint arXiv:1706.06906. 